\title{
Factors Influencing Job Satisfaction of Librarians in Federal and State University Libraries in Southern Nigeria
}

\author{
Chinyere N. Ikonne, Uloma D. Onuoha \\ Department of Information Resources Management, Babcock University, Ilishan-Remo, Nigeria \\ Email: cikonne@yahoo.com, ud onu@yahoo.com
}

Received 25 January 2015; accepted 9 February 2015; published 15 February 2015

Copyright (C) 2015 by authors and OALib.

This work is licensed under the Creative Commons Attribution International License (CC BY). http://creativecommons.org/licenses/by/4.0/

\section{(c) (i) Open Access}

\section{Abstract}

This study investigated the job satisfaction factors influencing the job satisfaction of librarians in Federal and State University libraries in Southern Nigeria. Job satisfaction is an important concept that can affect labor market behavior as it has a great influence on job-related behaviors such as productivity, work effort, absenteeism, turnover rates, and employee relations. The study adopted the survey research design. The population was made up of 500 librarians in thirty seven federal and state university libraries in Southern Nigeria. Sampling was enumeration as all members of the population were given the opportunity to participate. A questionnaire was used for data collection and was analyzed using percentages, standard deviation, and mean. Among other factors indentified, it was shown that job security, satisfactory relationship with my supervisor, satisfactory interaction with colleagues and satisfactory interaction with information user/customer/ clients were significant factors that influenced the librarians' job satisfaction. However, satisfaction with salary and fringe benefits, working condition, and opportunities to conduct research were rated low which signifies that the librarians are not satisfied with these job satisfaction facets. Based on this, recommendations such as library administrators considering improving the salary levels and the fringe benefits of the librarians, improving their working conditions; and granting the librarians opportunities to conduct research were made.

\section{Keywords}

Job Satisfaction, Librarian, Library Employee, Federal, State, University Libraries, Southern Nigeria Subject Areas: Library, Intelligence, Philology

\section{Introduction}

One of the key elements that have been linked to the success of any organization is the job satisfaction of the

How to cite this paper: Ikonne, C.N. and Onuoha, U.D. (2015) Factors Influencing Job Satisfaction of Librarians in Federal and State University Libraries in Southern Nigeria. Open Access Library Journal, 2: e1337.

http://dx.doi.org/10.4236/oalib.1101337 
employees. Every organization depends on its employees to carry out its functions. For this reason, [1] asserts that the ability of any organization to achieve its goals depends on its capability to attract, retain, and even maintain competent and satisfied staff into its employment. It is in view of this that he concludes that every organization that has goals to achieve should have satisfied and happy staff. [2] have also identified lack of job satisfaction as a predictor of quitting a job while [3] and [4] add that lack of job satisfaction could result in slowing down of work, job success, and job productivity; increase in workforce turnover, occupational accidents and complaints. It is on the basis that employees' job satisfaction in organizations has been receiving increasing attention.

The library, as have been noted by [5], is one of the key units of any educational institution and, especially, the University as it caters for the information needs of its users within and outside the University community. Job satisfaction of library workers should be considered crucial as it has to do with the appraisal of one's job or job experience. Considering the importance of this and for achieving its organizational goals and objectives, the library should ensure that its employees attain adequate job satisfaction.

\section{Objective of the Study}

The primary purpose of this study is to investigate the underlying factors of job satisfaction of the librarians in the Federal and State University libraries in Southern Nigeria. Specifically, this study wishes to determine those specific job satisfaction facets that influence the job satisfaction among these librarians.

\section{Review of Related Literature}

\subsection{Concept and Definition of Job Satisfaction}

Job satisfaction is a frequently studied subject in work and organizational literature. Researchers across the disciplines have written numerous articles concerning this topic. [6] argues that many authors have borrowed from psychology, business administration, human resources management and other disciplines of organizational science in an attempt to define, measure, and interpret the significance of job satisfaction in their areas of study.

The concept and definition of job satisfaction are intertwined. For [7], positive attitudes toward one's job are technically equivalent to job satisfaction. On the other hand, if one has negative attitudes toward one's job, it is equivalent to job dissatisfaction. He equally contends that job satisfaction, attitudes, and morality at work share the same definition. On the contrary, if workers have bad attitude about work, that shows that they are not satisfied with their work. In the same vein, [8] also argues that job satisfaction is an attitude that comes about as a result of either a positive or negative evaluative judgment one makes regarding one's job or job situation.

The view point of [9] is that Locke has provided one of the best and popular definitions of job satisfaction. [10] and [11] give a comprehensive definition of job satisfaction as a pleasurable or a positive emotional state resulting from the appraisal of one's job or job experience. Similarly, [12] and [13] affirm that job satisfaction is an indication of one's emotional reactions or state that emerges from one's cognitive appraisal of job experience to one's job.

Some other authors have argued in favor of the control of job satisfaction by factors intrinsic and extrinsic to the workers. [14] and [15] posit that these factors are those that surround the job itself and that they have the greatest impact on job satisfaction. Intrinsic factors come in the form of self worth, personal growth and professional development, and a supportive environment in which to work. However, in his later study, [14] argues that the intrinsic rewards may matter significantly less than is sometimes assumed once a greater range of influence is introduced. Therefore, he postulates that one needs to expand the range of causality. On the other hand, extrinsic factors are external job related variables that would include salary, supervision, and working conditions, rewards bestowed upon individual by the organization, supervisors, or even peers.

According to [16], job satisfaction has been seen to have uni-dimensional as well as multi-dimensional definitions. Spector (cited in [16]) elaborates on this by saying that the uni-dimensional definition of job satisfaction gives an overall definition of job satisfaction which, in the end, results in global measures. On the other hand, the multi-dimensional definition of job satisfaction gives a more elaborate type of definition. [17] refers to this as a multi-factorial construct definition of job satisfaction and states that this gives a more elaborate type of de- 
finition. It is assumed that multi-factorial construct definition of job satisfaction signifies that some satisfaction factors are more important than others.

In his argument concerning the concept and definition of job satisfaction, [18] argues that job satisfaction is anything that is capable of decreasing the tensions of workers. He says that stress comes from the basic human needs and that when these needs are met, tensions become fewer or completely gone and this eventually leads to job satisfaction. Based on this, [19] conclude that lower workplace hassles, higher recognition and reward, higher job control, and higher supervisory support are significantly correlated with higher job satisfaction.

\subsection{Determinants of Job Satisfaction}

Research studies have expatiated that workers who are satisfied at their workplaces show positive attitudes in their homes and make a psychologically healthy society. In connection with what generally determines job satisfaction, it has been established by [20] that many factors are involved in influencing job satisfaction. As been explained by [21], increased pay, staffing level, and benefits are among the most important factors related to higher job satisfaction. [10] adds other facets like recognition, working conditions, company and management all contribute to the achievement of higher job satisfaction. For [22] job satisfaction is influenced by the general job attitudes of employees such as attitude toward work group, general working conditions, attitudes toward the organization, monetary benefits and attitude toward supervision. Further, he opines that attitude toward supervisions is intricately connected with the individual's state of mind about the work itself and life in general.

Job satisfaction could be also affected by the nature of the job, its pervasive social climate, and the extent to which workers' peculiar needs are met. According to [1], working conditions that are similar to local and international standard and the extent to which they resemble work conditions of other professions in the locality are also determinant factors. [20] all affirm that job satisfaction can be influenced by factors such as the quality of the academics' relationships with their supervisors, the quality of the physical environment in which they work, and the degree of fulfillment in their work.

\subsection{Determinants of Job Satisfaction of Librarians}

According to [23], different variables predict employees' job satisfaction for different profession. This is due to the fact that different professions have to deal with different challenges and stressors which impact employees' job satisfaction. In relation to job satisfaction of librarians, [16] observes that much of the empirical effort that has been carried out among librarians in the developed countries have concentrated mainly on the antecedents of job satisfaction such as the differences in job satisfaction among male and female librarians and among librarians of the various units and divisions in the library. Further, that much of the studies have been focused on correlating librarians' job satisfaction with their age, working experience, salary and promotional opportunities in the library. The author further contends that very little effort has been made to examine the relationship between work and worker related variables such as "affective commitment, continuance commitment, job involvement, job autonomy, job feedback, role clarity, role conflict, age, organizational tenure and job tenure with librarians' job satisfaction” ([16], p. 70).

Ebru (in [24]) states that job satisfaction of the librarian has to do with the economical, social, and cultural conditions in that particular country. Low wages and lack of status and social security affect motivation, and therefore, job satisfaction cannot be discussed in the absence of motivation. Studies in relation to job satisfaction and librarianship have also consistently shown that there is a relationship between professional status and job satisfaction. High levels of job satisfaction are observed in those professions that are of good standing in society [24].

As has been reported by [25] on the study on the job satisfaction of academic librarians in relation to faculty status, it was revealed that librarians with academic rank were more satisfied than non-faculty groups. It was also found in the study that the greatest sources of satisfaction of the librarians were relationship with co-workers, assigned duties, and variety of work. Their sources of dissatisfaction were as a result of the lack of opportunities for promotion, recognitions of accomplishment and salary. [26] investigated the job satisfaction and organizational commitment of academic librarian in Nigerian Universities and discovered that the majority of the academic librarians were satisfied with their jobs because they had attractive salaries and wages. When [27] studied job motivation as a predictor of job satisfaction among professional and non-professional library staff, it was 
shown that library staff derived most satisfaction from salary/pay, library policies and administration, advancement and personal growth and job security. The study of Badawi (in [28]) on the level of job satisfaction of female librarians in Nigeria using Herzberg's Hygiene/Motivator factors of job satisfaction, revealed that female librarians in Nigeria are very satisfied with achievement, interpersonal relationships, recognition, growth/advancement, work itself, salary, personal life and job security.

Regarding the influence of job satisfaction on turnover intensions of library personnel in selected Universities in Nigeria, [29] states that there was no significant difference in the turnover intention of library personnel by their place of work (i.e. Federal and State Universities). In studying the management style and job satisfaction of library staff in the University of Niigata, Japan, [30] reports that there is no correlation between job satisfaction level and gender, age, position, education level and work experience. The study of library professionals by [31] revealed that their job satisfaction is not related to their sex, the type of library in which they worked, or their vocational needs, but rather on the characteristics of their job environments.

[32] surveyed the job satisfaction among librarians in Universities in the Khyber Pakhtunkhwa, Pakistan and found out that library professionals working in these institutions were slightly satisfied with the nature of their work but were dissatisfied with supervision, benefits, promotion. A study conducted by [33] on job satisfaction among Greek academic librarians, revealed that Greek academic librarians were most satisfied with the job itself, supervision, and working conditions and less satisfied with pay and promotion. When [34] investigated the job satisfaction of Canadian University librarians, they discovered that faculty-academic-status librarians were significantly more satisfied with their involvement in University affairs as well as in the promotion and tenure processes. However, they were not as satisfied with other dimensions of their work, such as workload and salary. Conversely, administrative librarians were significantly more satisfied with most of the major aspects of work being measured, and perceived themselves to be much more involved in library planning and University affairs than did non administrative librarians. [16] study on the correlates and predictors of job satisfaction among Malaysian academic librarians showed that affective commitment and organizational tenure had a predictive relationship with job satisfaction.

\section{Methodology}

The survey research design was used for this study. Study population consisted of 500 librarians in 37 Federal and State University libraries in Southern Nigeria. Sampling was enumerative as all members of the population were used for the study. A questionnaire statements used to measure the influence of job satisfaction were adapted.

\subsection{Presentation of Findings}

A total of 500 copies of the questionnaire were distributed out of which 359 copies were retrieved and seven of them were found not useful. But when summed together the response rate came to $72 \%$ which is considered adequate for a study of this nature.

\subsection{Demographic Characteristic of Respondents}

There were 352 respondents involved in this study, out of which were 189 women (53.7\%) while the male respondents were 163 (46.3\%). Majority of the respondents (40.3\%) were MLS/MLIS (Masters in Library Science/Masters in Library and Information Science) degree holders while 34.7\% were BLS/BLIS (Bachelor in Library Science/Bachelor in Library and Information Science) degree holders. About 3.7\% were MSc Inf (Masters of Science in Information) degree holders, $2.3 \%$ were $\mathrm{PhD}$ holders, while $1.1 \%$ and .3\% were BIRM (Bachelor in Information Resource Management) and MIRM (Masters in Information Resource Management) degree holders respectively. About eighteen percent (17.6\%) indicated their educational qualification as "others". Pertaining to the years of experience on the job, $41.5 \%$ of the respondents have spent between one to five years on their job, while 31\% have spent between 6 - 10 years. In addition, $22.7 \%$ have spent between 11 - 20 years, while $4.8 \%$ have spent between 21 and above years (Table 1 ).

Research Question: What are the factors that influence job satisfaction among librarian in the Federal and State University libraries in Southern Nigeria? (Table 2)

Indications from Table 2 show the factors that influence job satisfaction among the librarians in the Federal 
Table 1. Distribution of questionnaire.

\begin{tabular}{|c|c|c|c|c|}
\hline $\mathbf{S} / \mathbf{N}$ & University Library & $\begin{array}{c}\text { Copies of Questionnaire } \\
\text { Distributed }\end{array}$ & No. Returned & $\begin{array}{c}\text { Percentage } \\
\text { Response Rate }\end{array}$ \\
\hline 1 & Micheal Okpara University of Agiculture & 8 & 7 & 88 \\
\hline 2 & Abia State University & 5 & 5 & 100 \\
\hline 3 & University of Uyo & 5 & 3 & 60 \\
\hline 4 & Akwa-Ibom State University of Technology & 11 & 10 & 91 \\
\hline 5 & Anambra State University of Science and Technology & 4 & 4 & 100 \\
\hline 6 & Nnamdi Azikiwe University & 17 & 16 & 94 \\
\hline 7 & Niger Delta University & 19 & 14 & 74 \\
\hline 8 & Federal University, Otuoke & 4 & 4 & 100 \\
\hline 9 & Cross River State University and Technology & 10 & 8 & 80 \\
\hline 10 & University of Calabar & 30 & 13 & 43 \\
\hline 11 & Federal University of Petroleum Resources & 7 & 7 & 100 \\
\hline 12 & Delta State University & 10 & 10 & 100 \\
\hline 13 & Federal University, Ndufu-Alike & 2 & 2 & 100 \\
\hline 14 & Ebonyi State University & 12 & 10 & 83 \\
\hline 15 & Ambrose Alli University & 11 & 9 & 82 \\
\hline 16 & University of Benin & 22 & 16 & 73 \\
\hline 17 & Federal University Oye-Ekiti & 2 & 2 & 100 \\
\hline 18 & Ekiti State University & 11 & 7 & 64 \\
\hline 19 & Enugu State University of Science and Technology & 10 & 8 & 80 \\
\hline 20 & University of Nigeria & 37 & 30 & 81 \\
\hline 21 & Federal University of Technology, Owerri & 30 & 24 & 80 \\
\hline 22 & Imo State University & 9 & 8 & 89 \\
\hline 23 & University of Lagos & 17 & 11 & 65 \\
\hline 24 & Lagos State University & 11 & 9 & 82 \\
\hline 25 & Olabisi Onabanjo Universiy & 13 & 2 & 15 \\
\hline 26 & Tai Solarin University of Education & 15 & 11 & 73 \\
\hline 27 & University of Agriculture, Abeokuta & 30 & 2 & 7 \\
\hline 28 & Federal University of Technology, Akure & 19 & 17 & 90 \\
\hline 29 & Ondo State University of Science and Technology & 4 & 4 & 100 \\
\hline 30 & Adekunle Ajasin University, Akungba & 6 & 6 & 100 \\
\hline 31 & Obafemi Awolowo University, Ife & 15 & 13 & 87 \\
\hline 32 & Ladoke Akintola University of Technology, Ogbomoso & 13 & 11 & 85 \\
\hline 33 & Osun State University & 12 & 8 & 67 \\
\hline 34 & University of Ibadan & 30 & 17 & 57 \\
\hline 35 & University of Port Harcourt & 19 & 14 & 74 \\
\hline 36 & Rivers State University of Science and Technology & 10 & 8 & 80 \\
\hline \multirow[t]{2}{*}{37} & Ignatius Ajuru University of Education, Rumuolumeni & 10 & 9 & 90 \\
\hline & Total & 500 & 359 & $72 \%$ \\
\hline
\end{tabular}

and State University libraries in Southern Nigeria. The number one factor identified by the librarians that made their jobs satisfied is their job security with a mean score of 3.09 (58.5\%). This was followed by followed my relationship with my supervisor which got a mean score of 3.05 (62.2\%). My interaction with colleagues had a mean score of 2.97 (59.9\%) while my interaction with information user/customer/clients came with a mean score of 2.87 (64.5\%). Satisfaction with my job duties and job schedules had a mean score of 2.86 (65.3\%) while having job challenges received a mean score of 2.82 (59.4\%). Satisfaction with task variety got a mean score of 2.76 (60.2\%) while work autonomy came with a mean score of 2.72 (56.5\%). The communication climate in the workplace received a mean score of 2.68 (54\%) while my job status and recognition at work had a 
Table 2. Factors that influence job satisfaction of librarians.

\begin{tabular}{|c|c|c|c|c|c|c|c|}
\hline $\mathbf{S} / \mathbf{N}$ & Statement & $\begin{array}{l}\text { VD } \\
(\%)\end{array}$ & $\begin{array}{l}\text { DS } \\
(\%)\end{array}$ & $\begin{array}{l}S \\
(\%)\end{array}$ & $\begin{array}{l}\text { VS } \\
(\%)\end{array}$ & Mean & SD \\
\hline 1 & I am satisfied with my job security. & $\begin{array}{c}19 \\
(5.4)\end{array}$ & $\begin{array}{c}28 \\
(8.0)\end{array}$ & $\begin{array}{c}206 \\
(58.5)\end{array}$ & $\begin{array}{c}99 \\
(28.1)\end{array}$ & 3.09 & 0.755 \\
\hline 2 & My relationship with my supervisor is very satisfactory. & $\begin{array}{c}10 \\
(2.8)\end{array}$ & $\begin{array}{c}43 \\
(12.2)\end{array}$ & $\begin{array}{c}219 \\
(62.2)\end{array}$ & $\begin{array}{c}80 \\
(22.7)\end{array}$ & 3.05 & 0.680 \\
\hline 3 & My interaction with colleagues is satisfactory. & $\begin{array}{c}11 \\
(3.1)\end{array}$ & $\begin{array}{c}59 \\
(16.8)\end{array}$ & $\begin{array}{c}211 \\
(59.9)\end{array}$ & $\begin{array}{c}71 \\
(20.2)\end{array}$ & 2.97 & 0.704 \\
\hline 4 & $\begin{array}{l}\text { The interaction with information user/customer/clients is } \\
\text { satisfactory. }\end{array}$ & $\begin{array}{c}13 \\
(3.7)\end{array}$ & $\begin{array}{c}66 \\
(18.8)\end{array}$ & $\begin{array}{c}227 \\
(64.5)\end{array}$ & $\begin{array}{c}46 \\
(13.1)\end{array}$ & 2.87 & 0.671 \\
\hline 5 & My job duties/job schedules are very satisfactory. & $\begin{array}{c}14 \\
(4.0)\end{array}$ & $\begin{array}{c}64 \\
(18.2)\end{array}$ & $\begin{array}{c}230 \\
(65.3)\end{array}$ & $\begin{array}{c}44 \\
(12.5)\end{array}$ & 2.86 & 0.670 \\
\hline 6 & I am satisfied with the challenges of the job. & $\begin{array}{c}19 \\
(5.4)\end{array}$ & $\begin{array}{c}75 \\
(21.3)\end{array}$ & $\begin{array}{c}209 \\
(59.4)\end{array}$ & $\begin{array}{c}49 \\
(13.9)\end{array}$ & 2.82 & 0.733 \\
\hline 7 & I am satisfied with task variety. & $\begin{array}{c}16 \\
(4.5)\end{array}$ & $\begin{array}{c}88 \\
(25.0)\end{array}$ & $\begin{array}{c}212 \\
(60.2)\end{array}$ & $\begin{array}{c}36 \\
(10.2)\end{array}$ & 2.76 & 0.692 \\
\hline 8 & I am satisfied with work autonomy. & $\begin{array}{c}16 \\
(4.5)\end{array}$ & $\begin{array}{c}101 \\
(28.7)\end{array}$ & $\begin{array}{c}199 \\
(56.5)\end{array}$ & $\begin{array}{c}36 \\
(10.2)\end{array}$ & 2.72 & 0.705 \\
\hline 9 & The communication climate in the workplace is satisfactory. & $\begin{array}{c}29 \\
(8.2)\end{array}$ & $\begin{array}{c}93 \\
(26.4)\end{array}$ & $\begin{array}{c}190 \\
(54.0)\end{array}$ & $\begin{array}{c}40 \\
(11.4)\end{array}$ & 2.68 & 0.781 \\
\hline 10 & My job status/recognition at work is very satisfactory. & $\begin{array}{c}28 \\
(8.0)\end{array}$ & $\begin{array}{c}100 \\
(28.4)\end{array}$ & $\begin{array}{c}186 \\
(52.8)\end{array}$ & $\begin{array}{c}38 \\
(10.8)\end{array}$ & 2.66 & 0.774 \\
\hline 11 & I am satisfied with the managerial styles in my workplace. & $\begin{array}{c}37 \\
(10.5)\end{array}$ & $\begin{array}{c}101 \\
(28.7)\end{array}$ & $\begin{array}{c}164 \\
(46.6)\end{array}$ & $\begin{array}{c}50 \\
(14.2)\end{array}$ & 2.64 & 0.852 \\
\hline 12 & I am satisfied with the opportunities for regular promotion. & $\begin{array}{c}34 \\
(9.7)\end{array}$ & $\begin{array}{c}107 \\
(30.4)\end{array}$ & $\begin{array}{c}185 \\
(52.6)\end{array}$ & $\begin{array}{c}26 \\
(7.4)\end{array}$ & 2.58 & 0.766 \\
\hline 13 & There are opportunities for professional development. & $\begin{array}{c}39 \\
(11.1)\end{array}$ & $\begin{array}{c}108 \\
(30.7)\end{array}$ & $\begin{array}{c}176 \\
(50.0)\end{array}$ & $\begin{array}{c}29 \\
(8.2)\end{array}$ & 2.55 & 0.797 \\
\hline 14 & I am satisfied with my salary. & $\begin{array}{c}36 \\
(10.2)\end{array}$ & $\begin{array}{c}139 \\
(39.5)\end{array}$ & $\begin{array}{c}141 \\
(40.1)\end{array}$ & $\begin{array}{c}36 \\
(10.2)\end{array}$ & 2.50 & 0.813 \\
\hline 15 & My working condition is satisfactory. & $\begin{array}{c}47 \\
(13.4)\end{array}$ & $\begin{array}{c}140 \\
(39.8)\end{array}$ & $\begin{array}{c}137 \\
(38.9)\end{array}$ & $\begin{array}{c}28 \\
(8.0)\end{array}$ & 2.41 & 0.819 \\
\hline 16 & There are opportunities to conduct research. & $\begin{array}{c}50 \\
(14.2)\end{array}$ & $\begin{array}{c}146 \\
(41.5)\end{array}$ & $\begin{array}{c}131 \\
(37.2)\end{array}$ & $\begin{array}{c}25 \\
(7.1)\end{array}$ & 2.37 & 0.813 \\
\hline 17 & My fringe benefits are very satisfactory. & $\begin{array}{c}53 \\
(15.1)\end{array}$ & $\begin{array}{c}166 \\
(47.2)\end{array}$ & $\begin{array}{c}110 \\
(31.3)\end{array}$ & $\begin{array}{c}23 \\
(6.5)\end{array}$ & 2.29 & 0.800 \\
\hline
\end{tabular}

mean score of 2.66 (52.8\%). Satisfaction with regular promotion received a mean score of 2.55 (52.6\%). The study also that revealed that satisfaction with opportunities for professional development attracted a mean score of $2.58(50.0 \%)$.

Regarding satisfaction with my managerial styles in the work place, this received a mean score of 2.64 (46.6\%). In terms of my satisfaction with salary, the study also revealed a mean score of 2.50 (40.1\%) while satisfaction with my working condition had a mean score of 2.41 (38.9\%). The librarians rated satisfaction with opportunities to conduct research with a mean score of 2.37 (37.2\%) but with a dissatisfaction percentage rate of $41.5 \%$. My satisfaction with my fringe benefits got a mean score of 2.29 (31.3\%) and a dissatisfaction percentage rate of $47.2 \%$.

\section{Discussion of Finding}

From what has emerged from this study, it could be argued that many job satisfaction facets influenced the job satisfaction of the librarians in the Federal and State University libraries in Southern Nigeria. It is revealed that factors such as job security; satisfactory relationship with my supervisor; satisfactory interaction with colleagues; satisfactory interaction with information user/customer/clients; satisfactory job duties/job schedules; satisfaction with the challenges of the job; task variety and work autonomy; satisfactory communication climate in the 
workplace; and satisfactory job status/recognition at work are all significant conditions that elicit the achievement of job satisfaction among the librarians in the Federal and State University. Also, the study revealed low satisfaction with factors such as managerial styles in the workplace, salary, working conditions, opportunity to conduct research and fringe benefits.

Evidence from the table, therefore, shows that librarians identified job security as one of the significant factors that influenced their job satisfaction. This finding is in line with the findings of [27] and [28] who found in their various studies that having a secured job is of a great importance to librarians. Satisfactory relationship with my supervisor was another significant factor that influences librarians' job satisfaction and this finding is being supported by the findings of [20]. Librarians also derived job satisfaction as a result of their interaction with colleagues and this finding is similar to the findings of [25] who found the relationship with co-workers and variety of work (task variety) as important sources of job satisfaction. Further, satisfaction with opportunity for promotion was also one of the factors that influenced the job satisfaction of the librarians in the Federal and State University libraries in Southern Nigeria. This finding is being supported by the findings of [34] and [9] who found in their different studies that opportunity for job promotions is one of the factors that generate job satisfaction for librarians. But [25] and [32] found in their studies that one of the major sources of job dissatisfaction is the lack of opportunities for promotion. Finally, this study revealed low rate of satisfaction in connection with salary and this is line with the findings of [25] and [33] who discovered low satisfaction with pay in their studies. Satisfaction with my fringe benefits was also was rated low as [32] and [33] discovered in their studies that librarians were dissatisfied among other things with their benefits.

\section{Conclusion and Recommendations}

Based on the findings, it could be generally conclude that the librarians in the Federal and State University libraries in Southern Nigeria have indentified significant factors that influenced their job satisfaction. Therefore, on the basis on these findings, the study concludes that the librarians in the Federal and State University libraries are satisfied with their jobs. However, they are faced with the problems of low salary, poor fringe benefits, poor working condition, as well as lack of adequate opportunities to conduct researches. These could, however, lead to job dissatisfaction of the librarians. Therefore, based on these findings, the study recommends the following:

1) Library administrators should consider improving the salary levels and the fringe benefits of the librarians. It is believed that the more attractive their salary and fringe benefits are, the more satisfied and committed they will be in their services.

2) Library administrators should also improve the working condition of the librarians thereby creating good working environment that will promote good health and positive psychological well-being.

3) The library administrators should also grant the librarians enough opportunities to conduct researches. This could help them in their professional growth.

\section{References}

[1] Oshagbemi, T. (2000) How Satisfied Are Academics with Their Primary Tasks of Teaching Research and Administration and Management. International Sustainable in Higher Education, 1, 124-136. http://dx.doi.org/10.1108/1467630010371876

[2] Gazioglu, S. and Tansel, A. (2002) Job Satisfaction in Britain: Individual and Job-Related Factors. Economic Research Centre Working Papers in Economics 03/03. http://ideas.repec.org/p/met/wpaper/0303.html

[3] Iverson, R.D. and Deery, M. (2007) Turnover Culture in the Hospitality Industry. Human Resource Journal, 7, 471482.

[4] Lum, L.K. (2006) Explaining Nursing Turnover Intent: Job Satisfaction or Organizational Commitment. Journal of Organizational Behavior, 19, 305-320.

[5] Ikonne, C.N. (2014) Influence of Workstation and Work Posture Ergonomics on Job Satisfaction of Librarians in the Federal and State University Libraries in Southern Nigeria. IOSR Journal of Humanities and Social Science (IOSRJHSS), 19, 78-84.

[6] Murray, R.A. (1999) Job Satisfaction of Professional and Paraprofessional Library Staff at the University of North Carolina at Chapel Hill. A Master's Paper for the M.S. in L.S. Degree.

[7] Vroom, V.H. (2000) Work and Motivation. 3rd Edition, John and Wiley \& Sons, New York.

[8] Weiss, H.M. (2002) Deconstructing Job Satisfaction: Separating Evaluations, Beliefs, and Affective Experiences. Hu- 
man Resource Management Review, 12, 1-22. http://dx.doi.org/10.1016/S1053-4822(02)00045-1

[9] Lim, S. (2008) Job Satisfaction of Information Technology Workers in Academic Libraries. Library \& Information Science Research, 30, 115-121. http://dx.doi.org/10.1016/j.lisr.2007.10.002

[10] Locke, E.A. (2014) The Nature and Causes of Job Satisfaction: Handbook of Industrial and Organizational Psychology, Chicago, Rand McNally. http://scholar.google.com/scholar?q=Edwin+A.+Locke’s+Range+of+Affect+Theory+(1976)\&hl=en\&as_sdt=0\&as_vis $=1 \&$ oi $=$ scho

[11] Locke, E.A. (1983) The Nature and Causes of Job Satisfaction. In: Dunnette, M.D., Ed., Handbook of Industrial Psychology, Rand-McNally College Publishing Company, Chicago, 1297-1349.

[12] Hackman, J.R. and Oldham, G.R. (1976) Motivation through the Design of Work: Test of a Theory. Organizational Behavior and Human Performance, 16, 250-279. http://dx.doi.org/10.1016/0030-5073(76)90016-7

[13] Fritzsche, B.A. and Parrish, T.J. (2005) Theories and Research on Job Satisfaction. In: Brown, R. and Lent, R., Eds., Career Development and Counseling: Putting Theory and Research to Work, Wiley, New York, 180-202.

[14] Rose, M. (2005) Job Satisfaction in Britain: Coping with Complexity. British Journal of Industrial Relations, 43, 455467. http://dx.doi.org/10.1111/j.1467-8543.2005.00364.x

[15] Wilson, J.R. (2000) Fundamentals of Ergonomics in Theory and Practice. Applied Ergonomics, 31, 557-567. http://dx.doi.org/10.1016/S0003-6870(00)00034-X

[16] Karim, N.H.A. (2008) Investigating the Correlates and Predictors of Job Satisfaction among Malaysian Academic Librarians. Malaysian Journal of Library Information Science, 13, 69-88.

[17] Matzler, K., Fuchs, M. and Schubert, A. (2004) Employee Satisfaction: Does Kano’s Model Apply? Total Quality Management \& Business Excellence, 15, 1179-1198. http://dx.doi.org/10.1080/1478336042000255569

[18] Morse, N.C. (1953) Satisfaction in White Collar Job. University of Michigan Press, Ann Arbor.

[19] Mansell, A., Brough, P. and Cole, K. (2006) Stable Predictors of Job Satisfaction, Psychological Strain, and Employee Retention: An Evaluation of Organizational Change within the New Zealand Customs Service. International Journal of Stress Management, 13, 84-107. http://dx.doi.org/10.1037/1072-5245.13.1.84

[20] Lambert, E.G., Pasupuleti, S., Cluse-Tolar, T. and Jennings, M. (2008) The Impact of Work-Family Conflict on Social Work and Human Service Worker Job Satisfaction and Organizational Commitment: An Exploratory Study. Administration in Social Work, 30, 55-74.

[21] Sparks, S.A., Corcoran, K.J., Nabors, L.A. and Hovanitz, C.A. (2005) Job Satisfaction and Subjective Well-Being in a Sample of Nurses. Journal of Applied Social Psychology, 35, 922-938. http://dx.doi.org/10.1111/j.1559-1816.2005.tb02153.x

[22] Fajana, S. (2002) Human Resource Management: An Introduction. Labofin and Company, Lagos.

[23] Salama, A.M. and Courtney, L. (2013) The Impact of the Spatial Qualities of the Workplace on Architects' Job Satisfaction. International Journal of Architectural Research, 7, 52-64. http://archnet.org/library/documents/one-document.jsp?document_id=13526

[24] Tella, A., Ayeni, C.O. and Popoola, S.O. (2007) Work Motivation, Job Satisfaction, and Organizational Commitment of Library Personnel in Academic and Research libraries in Oyo State, Nigeria. Library Philosophy and Practice, 1-6.

[25] Horenstein, B. (1993) Job Satisfaction of Academic Librarians: An Examination of the Relationships between Satisfaction, Faculty Status, and Participation. College \& Research Libraries, 54, 255-269. http://dx.doi.org/10.5860/crl_54_03_255

[26] Owolabi, K.A. and Salaam, M.O. (2010) Job Satisfaction and Organizational Commitment of Academic Librarians in Nigerian Universities. Library Herald, 48, 162-170. http://www.indianjournals.com/ijor.aspx?target=ijor:lh\&volume=48\&issue=2\&article=007

[27] Amune, J.B. (2013) Job Motivation as a Predictor of Job Satisfaction among Professional and Non-Professional Library Staff in Ambrose Alli University, Ekpoma. International Journal of Innovative Research \& Development, 2. 1477-1497.

[28] Amune, J.B. (2014) A Comparative Study of the Determinants of Job Satisfaction among Male and Female Librarians in Public University Libraries in Edo State of Nigeria. International Journal of Education and Research, 2, 649-660. http://www.ijern.com/journal/July-2014/52.pdf

[29] Olusegun, S.O. (2013) Influence of Job Satisfaction on Turnover Intensions of Library Personnel in Selected Universities of South West Nigeria. Library Philosophy and Practice (E-Journal), 1-22. http://digitalcommons.unl.edu/cgi/viewcontent.cgi?article=2267\&context=libphilprac

[30] Dambawinna, K.P.K. (2012) Management Style and Job Satisfaction of Library Staff of University of Niigata, Japan. Annual Research Journal of SLSAJ, 1, 100-108. 
[31] Somvir and Kaushik, S. (2012) Job Satisfaction among Library Professionals in Haryana State. International Journal of Scientific and Research Publication, 2, 1-4.

http://citeseerx.ist.psu.edu/viewdoc/download?doi=10.1.1.387.7415\&rep=rep1\&type=pdf

[32] Togia, A., Koustelios, A. and Tsigilis, N. (2004) Job Satisfaction among Greek Academic Librarians. Library Information Science Research, 26, 373-383. http://dx.doi.org/10.1016/j.lisr.2004.01.004

[33] Leckie, G.J. and Brett. J. (1997) Job Satisfaction of Canadian University Librarians: A National Survey. College \& Research Libraries, 58, 31-47. http://dx.doi.org/10.5860/crl.58.1.31

[34] Popoola, S.O. (2011) Information Management and Organizational Behavior Inventory. Department of Library, Archival and Information Studies, University of Ibadan, Ibadan. 